\title{
Microstructural and Geochronological Analyses of Mesozoic Ductile Shear Zones in the Western Gyeonggi Massif, Korea: Implications for an Orogenic Cycle in the East Asian Continental Margin
}

\author{
Jeong-Yeong Park ${ }^{1}\left(\mathbb{D}\right.$, Seung-Ik Park ${ }^{1, * \mathbb{D}}$ and Taejin Choi ${ }^{2}$ (D) \\ 1 Department of Geology, Kyungpook National University, Daegu 41566, Korea; wjddud93@knu.ac.kr \\ 2 Department of Energy and Resources Engineering, Chosun University, Gwangju 61452, Korea; \\ tchoi@chosun.ac.kr \\ * Correspondence: psi@knu.ac.kr; Tel.: +82-53-950-5361
}

Received: 22 March 2020; Accepted: 15 April 2020; Published: 17 April 2020

\begin{abstract}
In response to orogenic cycles, the ductile shear zone records a complex crustal deformation history. In this study, we conducted a microstructural analysis of two NW-SE trending ductile shear zones (Deokjeok Shear Zone (DSZ) and Soya Shear Zone (SSZ)) in the Late Triassic post-collisional granites along the western Gyeonggi Massif in the Korean Peninsula. The DSZ, overlain by the Late Triassic to the Early Jurassic post-collisional basin fill (Deokjeok Formation), has asymmetric microstructures indicative of a top-down-to-the-northeast shear. Depending on the structural position, the SSZ, which structurally overlies the Deokjeok Formation, exhibits two contrasting styles of deformation. The lower portion of the SSZ preserves evidence of top-up-to-the-southwest shearing after top-down-to-the-northeast shearing; on the other hand, the upper portion only indicates a top-up movement. Given the primary deformation mechanisms of both quartz and feldspar, the deformation temperatures of DSZ and SSZ were estimated at $\sim 300-350{ }^{\circ} \mathrm{C}$ and $\sim 350-400^{\circ} \mathrm{C}$, respectively, indicative of the mid-crustal condition. New zircon U-Pb isotopic ages from mylonitic granite in the SSZ and volcanic rocks in the Deokjeok Formation, combined with previously published geochronological data, indicate that the post-collisional granites and volcano-sedimentary sequence were nearly contemporaneous (ca. 223-217 Ma) and juxtaposed because of the Late Triassic orogenic collapse and subsequent new orogenic event. In this study, we highlight the role of the extensional DSZ as a detachment propagated into the middle crust during the Late Triassic orogenic collapse. Our results report a deformational response to a transition from the collisional Songrim Orogeny to the subduction-related Daebo Orogeny in the western Gyeonggi Massif. This, in turn, provides essential insight into cyclic mountain building/collapse in the East Asian continental margin during the Mesozoic time.
\end{abstract}

Keywords: ductile shear zone; microstructure; deformation condition; Gyeonggi Massif; Mesozoic orogenic cycle; East Asian continental margin

\section{Introduction}

Orogeny is a series of geological mechanisms at convergent plate margins where mountain ranges are created [1,2]. Orogenic evolution is primarily controlled by the Wilson cycle [3], and involves repeated vertical thickening and thinning of continental crusts due to various factors, including the interplay between tectonic plates, gravitational potential energy, and isostasy [4-6]. Once the continental crust is thickened by orogenic processes, its isostatically compensated elevation leads to a high gravitational potential energy and drives mechanical collapse and vertical and lateral crustal 
flow [7-9]. Late- and post-orogenic magmatism thermally soften the orogenic crust as well as accelerate crustal extension and exhumation of the mid- or low-crustal materials [10]. Thermally weakened collapsed orogen with complex inherited structures may be vulnerable to external stress attributed to a subsequent orogenic event and provide a target for absorbing horizontal contraction via positive structural inversion [11].

In the Korean Peninsula, the western margin of the Gyeonggi Massif has been considered as a part of an orogenic belt in the East Asian continental margin, which had evolved via multiple tectonic events from the Proterozoic to the Mesozoic, in relation to the disruption and assemblage of the supercontinents Columbia (Nuna), Rodinia, and Pangea [12-15]. Since Early Mesozoic high-pressure metamorphic rock was discovered in the western Gyeonggi Massif [12], the lines of petrographic, geochemical, and geochronological studies have been conducted in the area and have given rise to several Korean collision zone models in the Permo-Triassic final amalgamation of the East Asia continent, including the Hongseong-Imjingang Belt [16], the Gyeonggi Marginal Belt [17], the Hongseong-Odaesan Belt [18], and the Crustal Detachment [19] models. The architectural and evolutionary history of the Permo-Triassic collision zone in and around the Korean Peninsula remain controversial because there remains a lack of understanding of the crustal modification owing to successive deformation events in relation to orogenic cycles. In the western Gyeonggi Massif, the micro- to macro-scale complex structural patterns must be clarified in connection with the timing of the deformations to test and refine collision models based on the concept of cyclic orogenic evolution.

The present study aims to provide new microstructural data from two ductile shear zones (the Deokjeok Shear Zone (DSZ) and Soya Shear Zone (SSZ)), which were defined by detailed field mapping in the Deokjeok and Soya islands in the western Gyeonggi Massif, and to constrain the kinematics and deformation conditions of ductile shearing. In this study, we present the timing of the syn-tectonic magmatism and sedimentation based on new zircon U-Pb ages from mylonitic granite and deformed volcanic rocks. The results will provide an improved understanding of an orogenic cycle in the western Gyeonggi Massif, thus reflecting spatial and temporal changes in governing the tectonic process of the Mesozoic East Asian continental margin.

\section{Geological Setting}

The Korean Peninsula comprises three Precambrian basement massifs: the Nangrim, Gyeonggi, and Yeongnam massifs, which are separated by the Paleozoic Imjingang and the Neoproterozoic to Paleozoic Okcheon belts ([20], Figure 1). These basement massifs are primarily composed of Paleoproterozoic (ca. 2.0-1.85 Ga) granite and migmatitic gneiss, minor schist, quartzite, marble, and amphibolite, and have experienced multiple tectono-thermal events related to subduction and collisional tectonics from the Paleoproterozoic to the Mesozoic [14,17,21-23].

In the previous two decades, various studies in the western Gyeonggi Massif have provided key evidence for the Neoproterozoic to Mesozoic plate marginal processes [12,13,15-17,24-32]. Furthermore, the Early Mesozoic high-pressure metamorphic imprint in the western Gyeonggi Massif is considered as a product of continental amalgamation in relation to the closure of the Paleo-Tethys Ocean [12,14,16,25,28], and has tracked the eastward extension of the Qinling-Dabie-Sulu Belt in China, even though the location of the suture zone remains controversial. The Early Mesozoic crustal thickening event in the Korean Peninsula, caused by continental collision, has been referred to as the Songrim Orogeny, which is temporally correlated with the Indosinian Orogeny in southeastern China [33-35]. The overthickened crust of the western Gyeonggi Massif was affected by Late Triassic post-collisional magmatic activity and metamorphism supposedly induced by the lithospheric delamination or oceanic slab break-off [36-38]. In accordance with the post-collisional thermal pulses, the gravitationally unstable crust collapsed and stretched, leading to the exhumation of deeply buried rocks and the formation of non-marine sedimentary basins [29,38]. As the Paleo-Pacific Plate subducted under the Eurasian Plate, the western Gyeonggi Massif was then located on a continental arc during the Early to Middle Jurassic [39-41]. During the Late Jurassic to Early Cretaceous, the arc magmatism ceased because of slab shallowing, and the flat/low 
angle subduction of the Paleo-Pacific Plate caused basement-involved shortening and basin inversion in the western Gyeonggi Massif [30]. The magmatic and non-magmatic tectonic processes related to the subduction of the Paleo-Pacific Plate have been referred to as the Daebo Orogeny [30,42]. In the western Gyeonggi Massif, the Deokjeok and Soya islands are natural laboratories used to characterize the Mesozoic cyclic mountain-building/destruction processes (Figure 1). The islands are primarily composed of Paleoproterozoic gneisses, Neoproterozoic and Paleozoic schists, Late Triassic post-collisional intrusions, and Late Triassic to Early Jurassic non-marine sedimentary sequence (Deokjeok Formation) (Figure 2, [43,44]). The lithologic distribution is markedly controlled by the NW-SE trending macro-scale thrusts and shear zones (Figures 2 and 3). Note that the Deokjeok Formation comprises isolated sedimentary packages separated by the basement-involved Buk-ri Thrust (Figure 2), possibly indicating independent sub-basins.

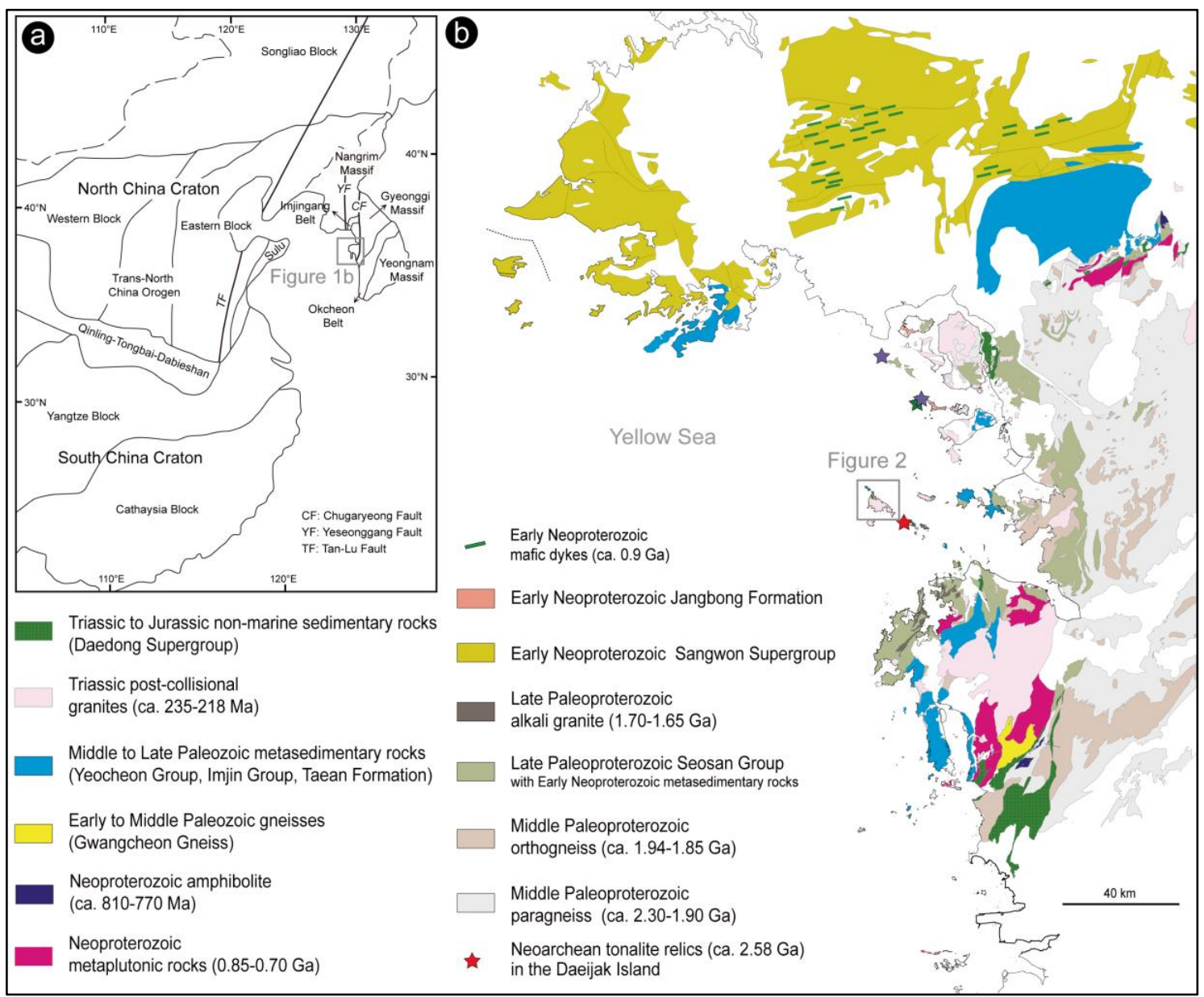

Figure 1. (a) Simplified tectonic map of the Korean Peninsula and adjacent areas (modified from [45,46]). (b) Geologic map of the western Gyeonggi Massif (modified from [47]). The gray rectangular box denotes the area of Figure 2. 


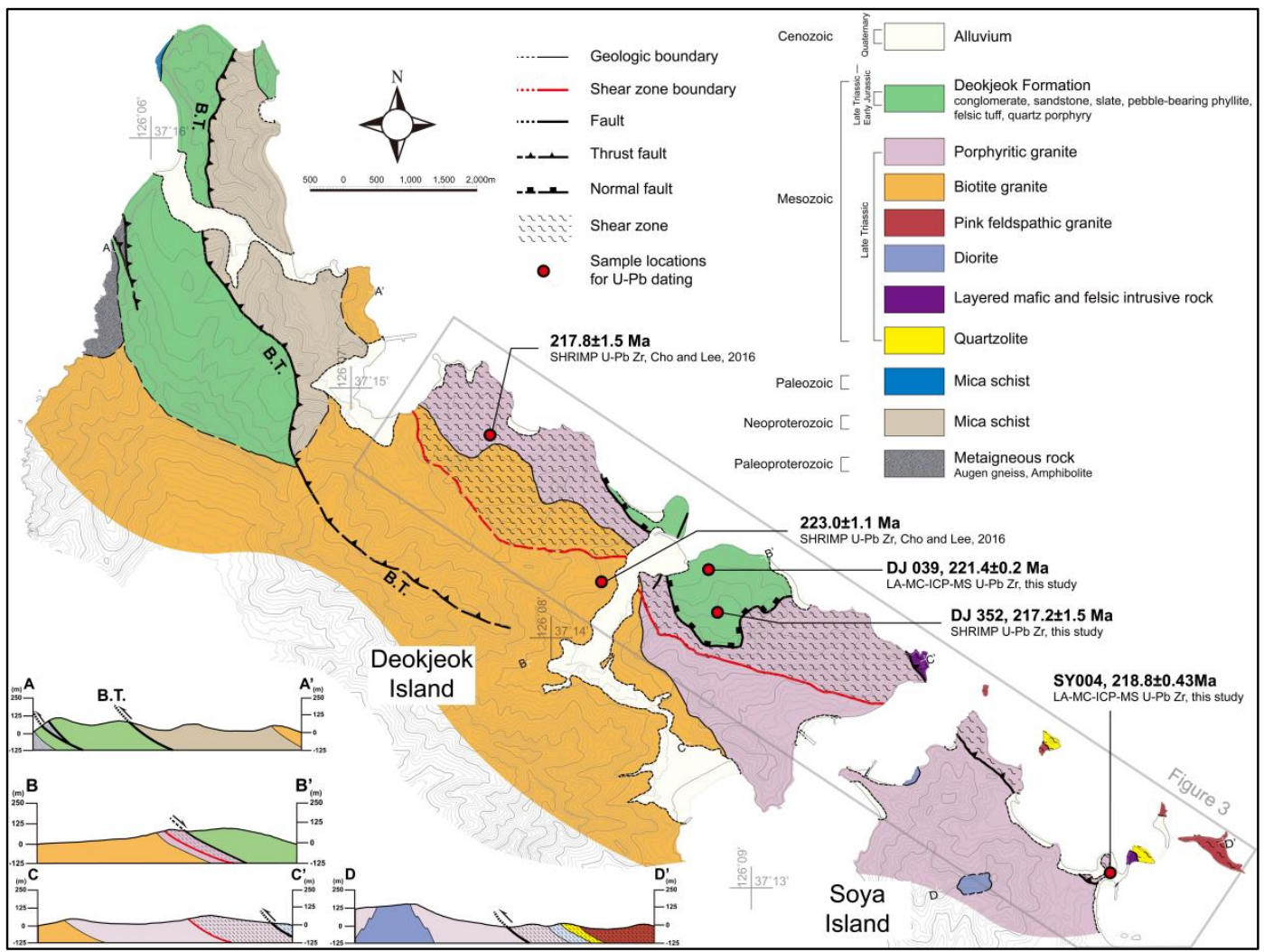

Figure 2. Geological map and cross-sections of the Deokjeok and Soya islands. Sample locations for U-Pb dating are shown on the map. The gray rectangle indicates the location of Figure 3. B.T.-Buk-ri Thrust.

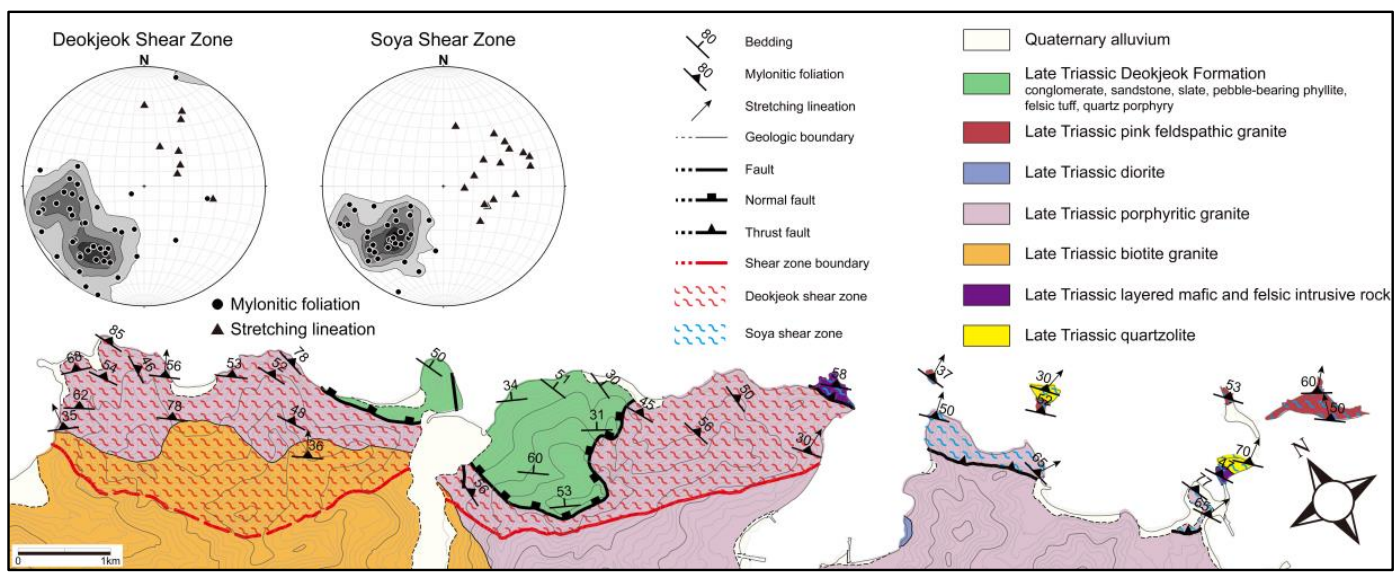

Figure 3. Detailed structural map of the northeastern coast of the Deokjeok and Soya islands. Equal-area stereograms indicate poles to mylonitic foliation and stretching lineation in the Deokjeok and Soya shear zones.

The hanging wall of the Buk-ri Thrust, which is the focus of this study, has a complex structural architecture (Figure 3). Porphyritic granite, which locally has a magmatic foliation, is extensive in the hanging wall domain (Figures 2 and 3). Along the northeastern coasts of the Deokjeok and Soya islands, the porphyritic granite has a strong mylonitic foliation (Figure 3). The Deokjeok Formation above the mylonitized porphyritic granite is weakly metamorphosed and comprise conglomerate, sandstone, slate, pebble-bearing phyllite, felsic tuff, and quartz porphyry (Figure 4). The quartz porphyry and the felsic tuff are consistently concordant with the sedimentary layers (Figure $4 \mathrm{~b}$ ), possibly indicating syn-sedimentary volcanism. The contact between the volcano-sedimentary sequence and the underlying mylonitized porphyritic granite is a normal fault (Figures 3 and 5). In the hanging wall of the 
Buk-ri Thrust, the Deokjeok Formation is structurally overlain by porphyritic granite, pink feldspathic granite, quartzolite, and layered mafic and felsic intrusion, all of which are strongly mylonitized.
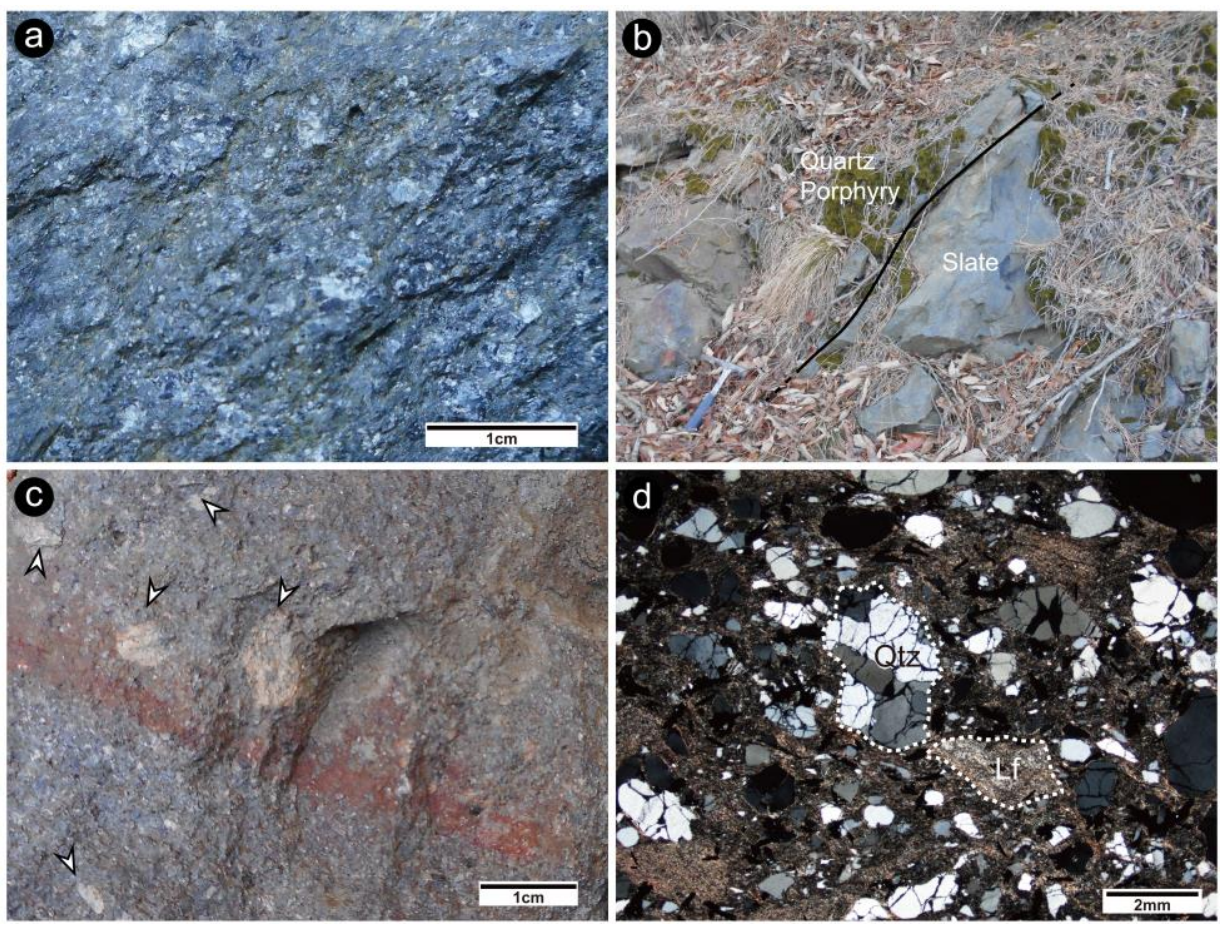

Figure 4. Photographs showing volcanic rocks in the Deokjeok Formation in the hanging wall of the Buk-ri Thrust. (a) Outcrop photograph of quartz porphyry. (b) Outcrop photograph showing the concordant relationship between the quartz porphyry and sedimentary layers. (c) Outcrop photograph of a felsic tuff, including sub-rounded to sub-angular, various sized lithic fragments (white arrow). (d) Photomicrograph (cross-polarized light) of a felsic tuff showing fractured quartz crystals and lithic fragments in the sericite-bearing finer matrix. Abbreviations: Qtz-Quartz, Lf-Lithic fragment.
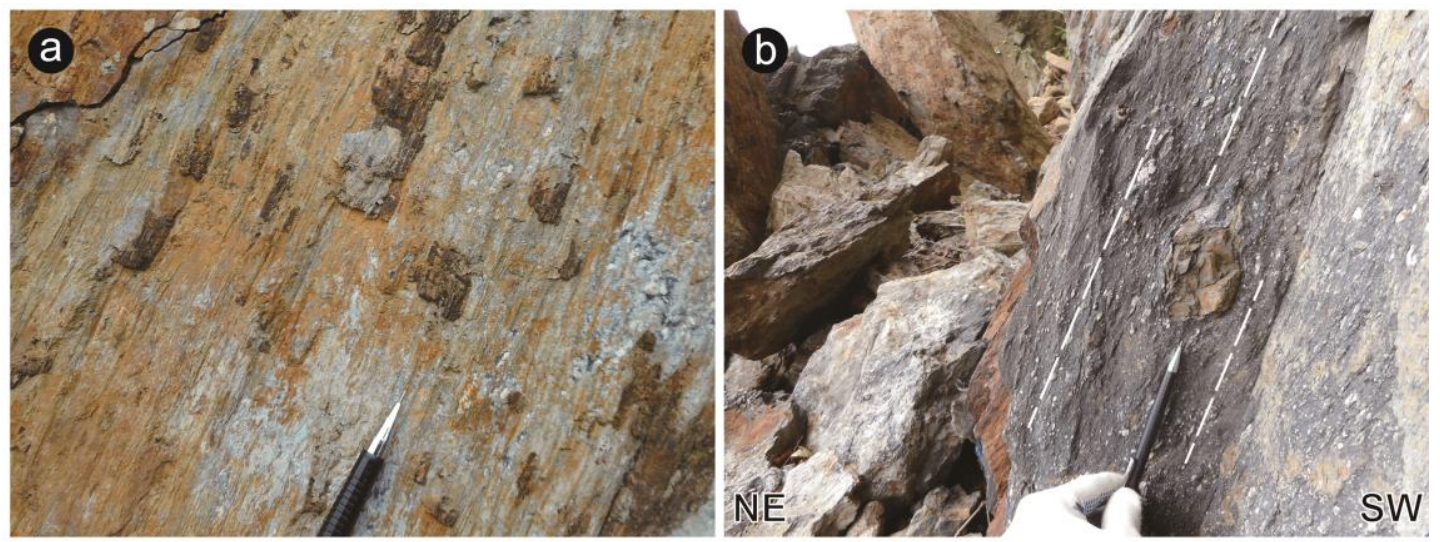

Figure 5. Outcrop photographs of a normal fault juxtaposing volcano-sedimentary sequences in the Deokjeok Formation and mylonite in the DSZ. (a) Slickenfibres on the fault surface indicative of top-down movement. (b) Foliated cataclasite zone along the normal fault.

\section{Deokjeok and Soya Shear Zones}

In the Late Triassic granites along the northeastern coasts of the Deokjeok and Soya islands, the overall NW-SE trending ductile shear zones are well developed. In this study, based on their structural position, we defined two shear zones: the Deokjeok Shear Zone (DSZ), which is structurally overlain by 
the Deokjeok Formation, and the Soya Shear Zone (SSZ), which is structurally overlying the Deokjeok Formation (Figure 3).

The DSZ has a width of at least $1 \mathrm{~km}$ (Figure 3). The mylonitic foliation is defined by the arrangement of quartz aggregates and mica, and strikes WNW-NNE and dips consistently northeastward at $35^{\circ}-80^{\circ}$. The foliation surface is marked by a NE-plunging (down-dip) stretching lineation, which is recognized as a long axis of $\mathrm{K}$-feldspar porphyroclast. In the DSZ outcrop, the S-C structure is indicative of a top-down-to-the-northeast sense of movement (Figure 6a). In the DSZ, the fabric intensity tends to increase from southwest to northeast in the map area. The northeastern boundary of the DSZ is a normal fault in contact with the Deokjeok Formation, and foliated cataclasite with a thickness of at least several meters (Figure 5) occurs along the boundary.
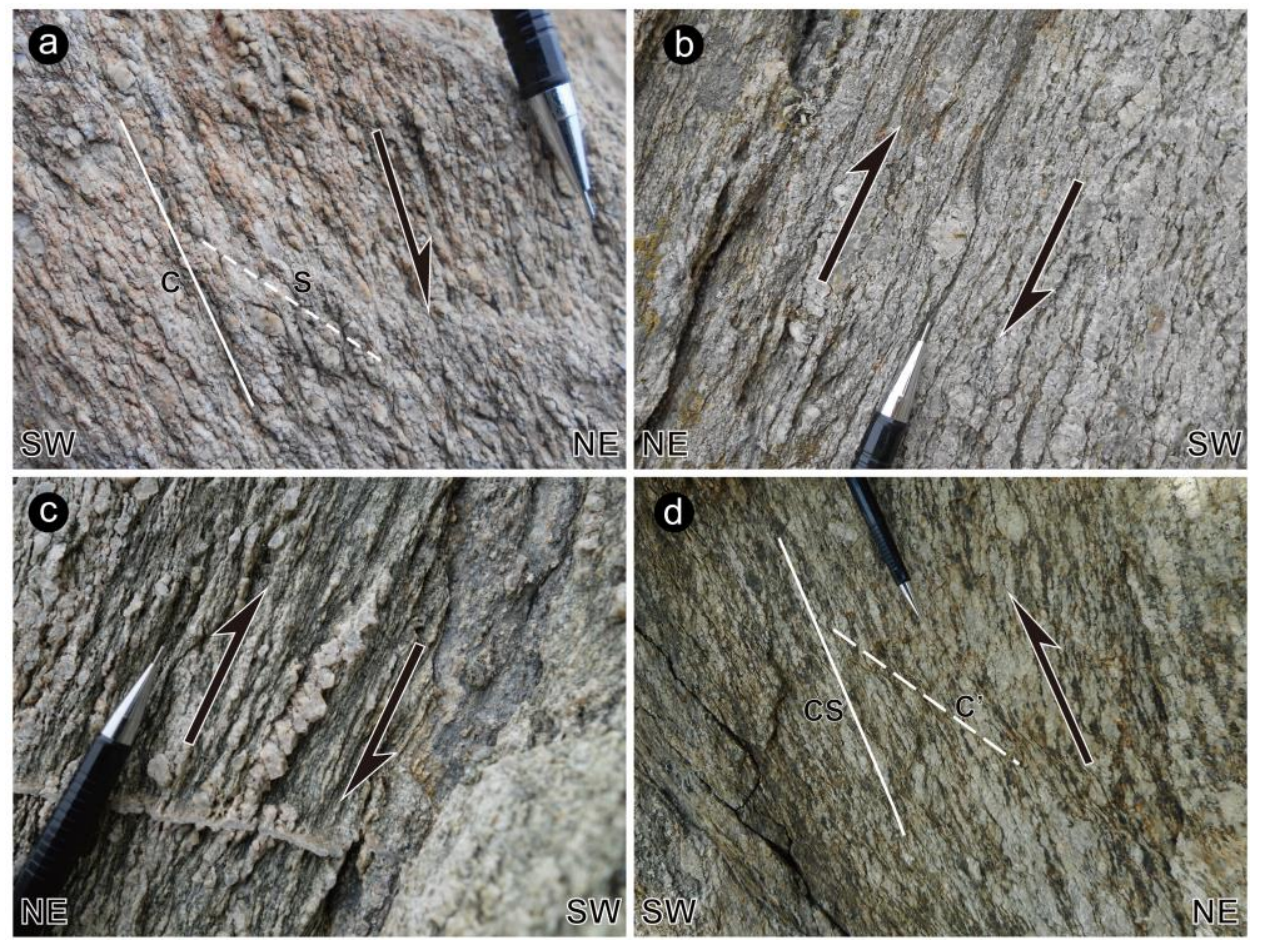

Figure 6. Outcrop-scale shear sense indicators in the Deokjeok Shear Zone (DSZ) (a), and the Soya Shear Zone (SSZ) (b-d). (a) S-C structure. (b) $\sigma$-type strain shadow. (c) Antithetic shear fracture (bookshelf structure). (d) Extensional crenulation cleavage ( $C^{\prime}$ shear band) inclined at $30^{\circ}-40^{\circ}$ to the earlier CS-foliation.

The SSZ is at least $1 \mathrm{~km}$ wide and its southwestern boundary is defined by a thrust fault (Figure 3). In the SSZ, mylonitic foliation is defined by the alignment of mica and quartz aggregates, and strikes NW to NNW and dips northeastward at $20^{\circ}-85^{\circ}$ (Figure 3). A strong down-dip stretching lineation occurs on the mylonitic foliation. Outcrop-scale asymmetrical structures, including $\sigma$-type strain shadow, antithetic shear fracture of K-feldspar porphyroclast, and extensional crenulation cleavage $\left(\mathrm{C}^{\prime}\right.$ shear band), indicate a top-up-to-the-southwest sense of movement in the SSZ (Figure 6b-d).

\section{Microstructures}

To further interpret deformation conditions and kinematics, we observed the microstructures of the mylonitic granites in the DSZ and SSZ. For microstructural analysis, all thin sections were cut perpendicular to mylonitic foliation and parallel to stretching lineation, thus representing the $\mathrm{XZ}$ plane of finite strain within the shear zones. 


\subsection{Deokjeok Shear Zone}

Original quartz grains in the mylonitic granite from the DSZ show patchy undulatory extinction and deformation bands caused by recovery-accommodated dislocation creep (Figure 7a,b; [48]). Recrystallized quartz grains are slightly elongated, with aspect ratios between 2:1 and 3:1, and we observed two types of recrystallized quartz grains along the original quartz grain boundaries (Figure 7b): (1) irregular-sized new grains by bulging recrystallization much smaller than the original grains and (2) regular-sized new grains by subgrain rotation, which are the same size as the subgrains. In the DSZ, the former is more common compared the latter. K-feldspar porphyroclasts have a maximum long axis of $\sim 8 \mathrm{~mm}$ wrapped by quartz aggregates and mica. The majority of the feldspars show quartz-filled intragranular microfractures (Figure 7a) subparallel with mineral cleavage and rarely display microstructures indicating crystal plasticity. The deformation band (Figure $7 \mathrm{c}$ ) and undulatory extinction are occasionally observed in small feldspar grains of less than $\sim 2 \mathrm{~mm}$ in size. All kinematic indicators, including $\sigma$-type asymmetric strain shadow around feldspar porphyroclasts and S-C fabric, demonstrate a top-down-to-the-northeast shear sense (Figure $7 \mathrm{~d}$ ).
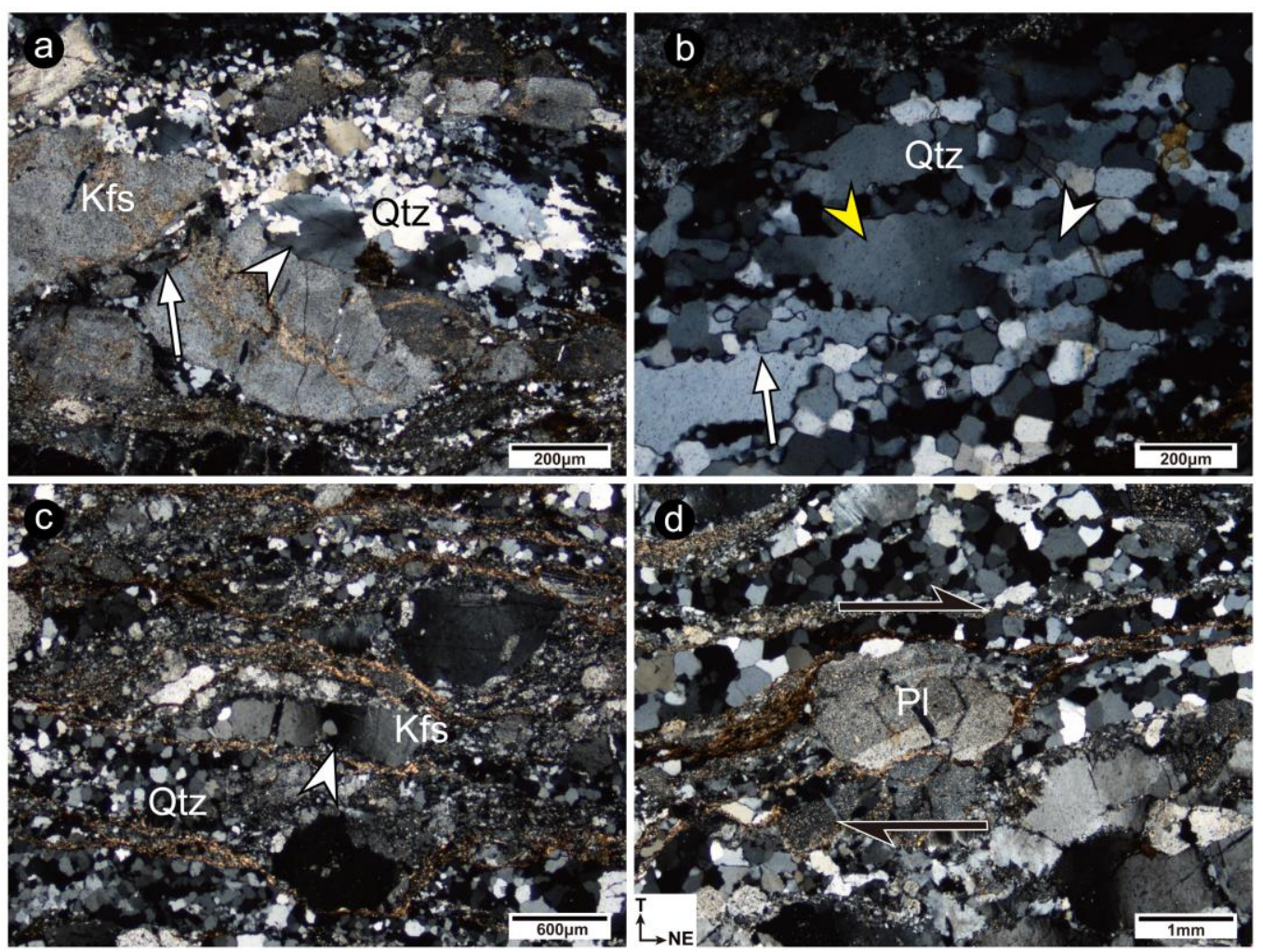

Figure 7. Photomicrographs (cross-polarized light) showing microstructures of the Deokjeok Shear Zone (DSZ). (a) Deformation band in quartz (arrow) and intragranular fractures in K-feldspar (long arrow). (b) Recrystallized quartz grains through bulging (long arrow) and subgrain rotation (arrow), and patchy undulatory extinction in original quartz grain (yellow arrow). (c) Deformation band in K-feldspar. (d) $\sigma$-type strain shadow indicating top-down-to-the-northeast sense of shear. Abbreviations: Qtz-Quartz, Kfs-K-feldspar, Pl-Plagioclase. 
Microstructures of quartz and feldspar in the DSZ indicate a low-temperature deformation condition during the extensional (top-down) shearing. The quartz grains with low aspect ratios mainly formed through bulging recrystallization, which is representative of the BLG (bulging recrystallization) I domain of Stipp et al. $[49,50]$, indicate a deformation temperature range of $\sim 280-350{ }^{\circ} \mathrm{C}$. The pervasively fractured feldspar grains, which locally show a deformation band and undulatory extinction is typical of Zone 2 of the Pryer [51], and thus suggest deformation at $\sim 300-400{ }^{\circ} \mathrm{C}$. Thus, based on the microstructures of both quartz and feldspar, the estimated deformation temperature of the DSZ is $\sim 300-350{ }^{\circ} \mathrm{C}$, which is indicative of the mid-crustal condition.

\subsection{Soya Shear Zone}

In original quartz grains in the mylonitic granite of the SSZ, intragranular plastic deformation features, such as undulatory extinction, deformation band, and subgrain boundary, are clearly observed (Figure 8a). Recrystallized quartz grains formed by subgrain rotation and bulging are developed, particularly along the original quartz grain boundaries (Figure 8a). Recrystallized quartz grains show relatively high aspect ratios (up to 5:1) and occasionally define steady-state foliation inclined at $40^{\circ}-50^{\circ}$ to the main mylonitic foliation (Figure $8 \mathrm{~b}$ ). K-feldspar porphyroclasts with a long axis of up to $1 \mathrm{~cm}$ in length are wrapped by recrystallized quartz grains and mica. The microstructure in feldspar is dominated by intragranular fracture subparallel to cleavage, which is filled with both quartz and white mica (Figure 8c). Patch undulatory extinction, deformation twin, strain-related myrmekite, and flame perthite are observed along the feldspar grain boundaries (Figure $8 c, d$ ). The asymmetric strain shadow around $\mathrm{K}$-feldspar porphyroclasts is primarily composed of recrystallized quartz grain (Figure 8e). The quasi-plastic deformation features in the SSZ are locally imprinted by the elastico-frictional deformation, as has been demonstrated by the dominant cataclastic microstructures along the lower (southwestern) boundary zone (Figure 8f).

Depending on their structural position, the microstructures of the mylonitic granites in the SSZ represent two contrasting kinematic styles. In the upper (northeastern) portion of the SSZ, all asymmetric microstructures indicate a top-up-to-the-southwest sense of shear (Figures $6 \mathrm{~b}-\mathrm{d}$ and $8 \mathrm{~d}, \mathrm{e}$ ). However, in the lower (southwestern) portion of the SSZ, a kinematic inversion is recognized. Most kinematic indicators in the lower portion of the SSZ, including a $\sigma$-type asymmetric strain shadow and stair-stepping quartz band, illustrate a top-up-to-the-southwest sense of movement; however, a part of the quartz lenses shows a relict of steady-state foliation indicating a top-down-to-the-northeast shear sense (Figure $8 b$ ). The cross-cutting relationship is interpreted to mean the normal slip (extensional shearing) occurred earlier compared to the reverse slip (contractional shearing).

The quartz grains with relatively high aspect ratios, formed by both bulging and subgrain rotation, are typical of the BLG II domain of Stipp et al. [49,50], thus indicating a deformation temperature range of $\sim 350-400^{\circ} \mathrm{C}$. The feldspars showing pervasive intragranular fractures and local evidence for recovery, such as patch undulatory extinction, strain-related myrmekite, and flame perthite, are representative of Zone 2 of the Pryer [51], which suggest deformation at $\sim 300-400{ }^{\circ} \mathrm{C}$. To summarize, the deformation temperature of the SSZ of $\sim 350-400{ }^{\circ} \mathrm{C}$ is estimated based on the microstructures of both quartz and feldspar, reflecting a mid-crustal condition. The crystal plastic deformation overprinted by dominant cataclasis along the southwestern boundary of the SSZ possibly indicates that the highly strained rocks were brought closer to the surface through uplift and erosion during progressive contractional shearing. 

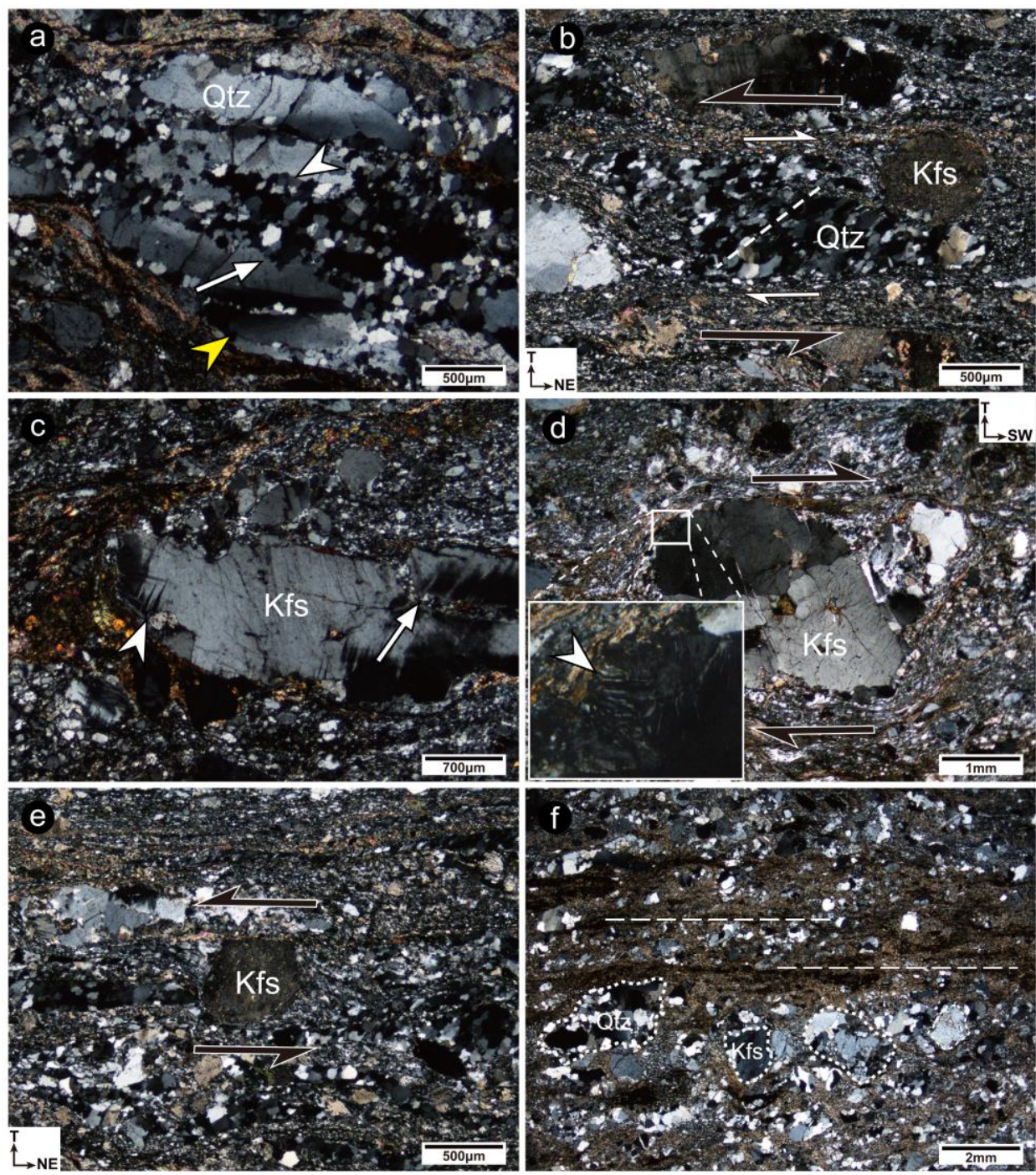

Figure 8. Photomicrograph (cross-polarized light) showing microstructures of the Soya Shear Zone (SSZ). (a) Recrystallized quartz grains through bulging (long arrow) and subgrain rotation (arrow), and undulatory extinction in original quartz grain (yellow arrow). (b) Asymmetric quartz lens indicating a top-up-to-the-southwest sense of shear. Relict of steady-state foliation in the quartz lens (dashed line) implies an opposite shear sense. (c) Deformation twin (arrow) and intragranular fractures (long arrow) filled with quartz and white mica in feldspar. (d) Asymmetric occurrence of strain-related myrmekite in feldspar, indicating a top-up-to-the-southwest sense of movement. (e) $\sigma$-type strain shadow indicating a top-up-to-the-southwest sense of shear. (f) Foliated cataclasite along the lower boundary of the SSZ. Abbreviations: Qtz-Quartz, Kfs-K-feldspar.

\section{U-Pb Geochronology}

To constrain the timing of syn-tectonic magmatism and sedimentation, we conducted zircon U-Th-Pb isotopic age dating for three samples (DJ039, DJ352, and SY004) from mylonitized porphyritic granite in the SSZ and deformed volcanic rocks in the Deokjeok Formation. Zircons were selected from heavy mineral concentrates, and mounted in epoxy disks along with secondary zircon standards FC-1 (ca. 1099 Ma; [52], with DJ352) or Plešovice (ca. 337 Ma; [53], with SY004 and DJ039). The internal textures of the zircons were imaged via cathodoluminescence $(C L)$ and backscattered electron imaging (BSEI) using a scanning electron microscope (JEOL 6610LV) at the Korea Basic Science Institute (KBSI), Ochang Campus, Cheongju, South Korea. The Pb-Th-U isotopic data were obtained using the sensitive high-resolution ion microprobe (SHRIMP) for DJ352 and the nu plasma II multi-collector inductively 
coupled plasma mass spectrometer combined with a $193 \mathrm{~nm}$ ArF excimer laser ablation system (LA-MC-ICP-MS) for DJ039 and SY004 at the KBSI Ochang Campus. For SHRIMP and LA-MC-ICP-MS dating, the instrumental conditions and analytical procedures were the same as those described by Williams et al. [36] and Lee et al. [32]. Acquired ${ }^{206} \mathrm{~Pb} /{ }^{238} \mathrm{U}$ age of the FC-1 zircon grains was ca. 1099 $\pm 4.3 \mathrm{Ma}(2 \sigma, n=17, \mathrm{MSWD}=1.20)$. The Plešovice zircons yielded ages of ca. $337.20 \pm 0.26 \mathrm{Ma}(2 \sigma$, $n=76, \mathrm{MSWD}=0.065)$ for SY004 and ca. $337.50 \pm 0.33 \mathrm{Ma}(2 \sigma, n=53, \mathrm{MSWD}=0.116)$ for DJ039. The analyses were targeted on the rims of the zircon grains to constrain the crystallization ages of the samples. The isotopic ages were calculated per the constants recommended by the International Union of Geosciences (IUGS) Subcommission on Geochronology [54]. Plotting of the data on concordia diagrams and the age determination were conducted using Squid 2.50, Isoplot 3.71 [55,56], and Iolite $2.5[57,58]$. We used ${ }^{206} \mathrm{~Pb} /{ }^{238} \mathrm{U}$ ages for zircons younger than $1.0 \mathrm{Ga}$, and ${ }^{207} \mathrm{~Pb} /{ }^{206} \mathrm{~Pb}$ ages for zircons older than $1.0 \mathrm{Ga}$.

\subsection{Deformed Felsic Tuff in the Deokjeok Formation (DJ352)}

The zircons from samples DJ352 occur as stubby to prismatic (aspect ratios 1-5.7), subhedral to euhedral, and fine- to large-sized (60-410 $\mu \mathrm{m}$ in diameter) grains with rare rounded terminations. Most of the zircons display marked oscillatory or sector zoning, which is typical of zircons from igneous rocks (Figure 9a). Some zircon grains exhibit inherited, anhedral to subhedral zoned cores and weakly zoned overgrowths with dark CL images (Figure 9a). The data from 52 analytic spots reveal a broad range of $U$ contents (52-3282 ppm) and Th/U ratios (0.05-1.66) (Table S1). The Th/U ratios are nearly above 0.1 .
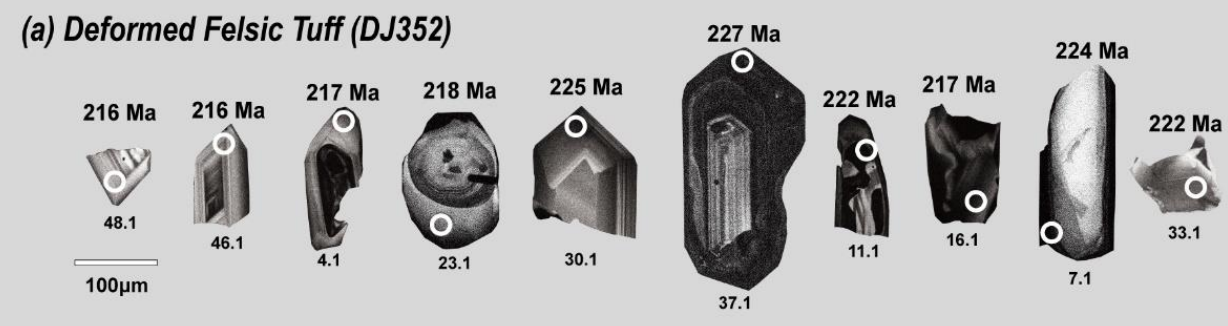

(b) Deformed Quartz Porphyry (DJ039)
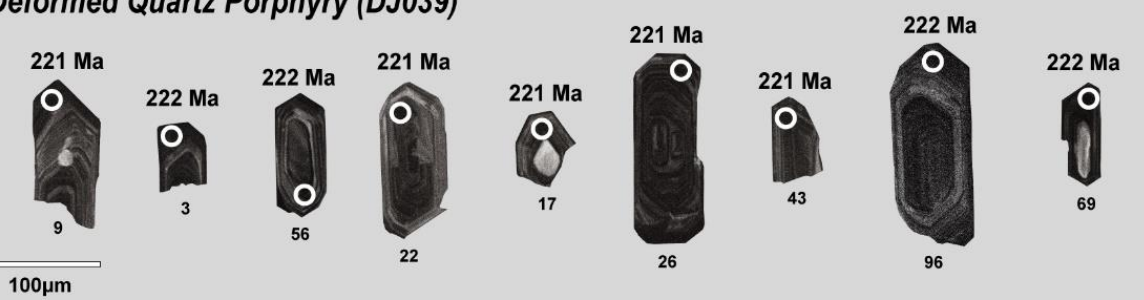

(c) Mylonitized Granite (SY004)

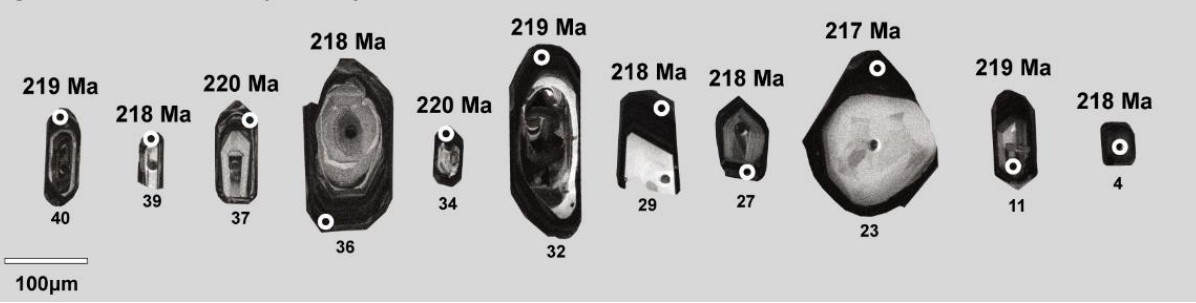

Figure 9. Scanning electron microscope cathodoluminescence (CL) images of sectioned zircon grains from (a) a deformed felsic tuff, (b) deformed quartz porphyry, and (c) mylonitized porphyritic granite.

The apparent ages of the analyzed spots range widely from the Paleoproterozoic to Late Triassic: 2430, 2237, ca. 1869-1819, 1776, 1681, ca. 953-814, 282, 254, 246, 238, ca. 237-210 Ma (Table S1, Figure 10a). Approximately $70 \%$ of the apparent ages fall into the Late Triassic period. Notably, 
there are two Late Triassic zircon populations yielding weighted mean ages defined by over eight analyses: $223.9 \pm 1.0 \mathrm{Ma}(n=17, \mathrm{MSWD}=0.89)$ and 217.2 $\pm 1.5 \mathrm{Ma}(n=8 ; \mathrm{MSWD}=0.25)($ Figure 10b). The youngest weighted mean age, ca. $217 \mathrm{Ma}$, likely indicates the timing of syn-sedimentary felsic volcanism related to the emplacement of the analyzed tuff layer.

(a)

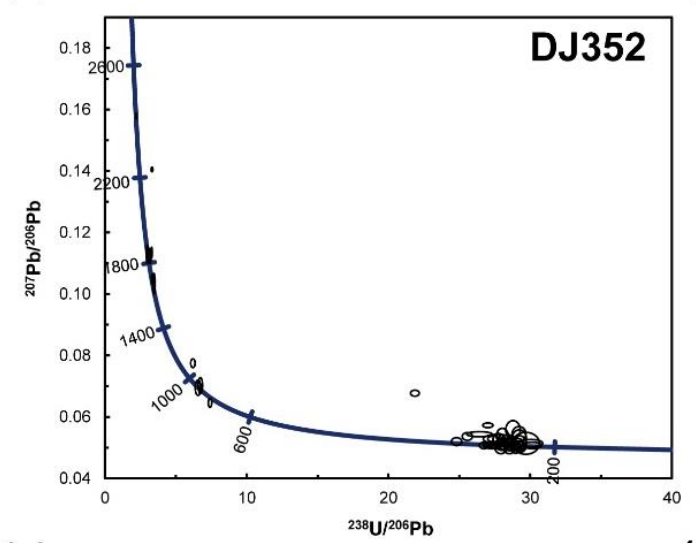

(c)

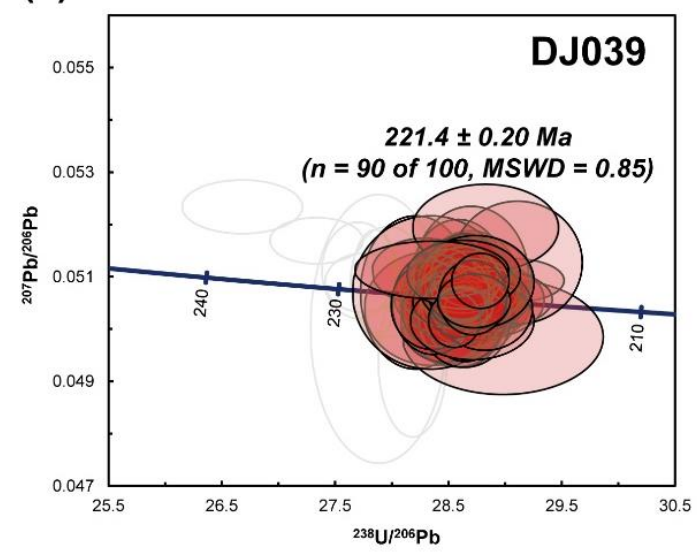

(b)

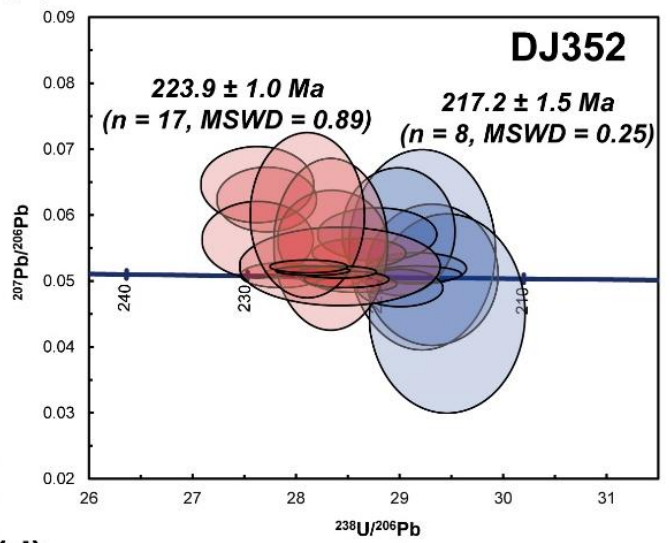

(d)

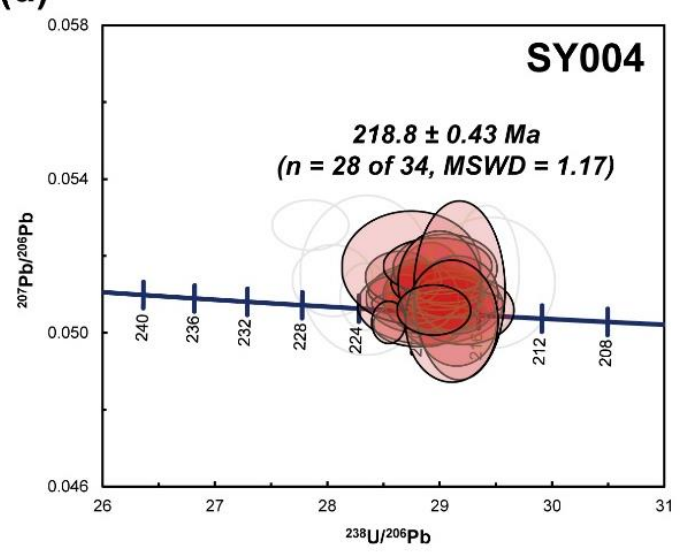

Figure 10. Concordia plots of zircon SHRIMP and LA-MC-ICP-MS U-Pb isotopic data from the deformed felsic tuff $(\mathbf{a}, \mathbf{b})$, deformed quartz porphyry (c), and mylonitized porphyritic granite (d).

\subsection{Deformed Quartz Porphyry in the Deokjeok Formation (DJ039)}

The zircons from samples DJ039 occur as stubby to prismatic (aspect ratios of 1.0-5.6), subhedral to euhedral, and fine- to medium-sized (25-190 $\mu \mathrm{m}$ in diameter) grains. Most zircons exhibit oscillatory zoning indicative of their igneous origin (Figure 9b). The data from 100 analytic spots reveal a broad range of $U$ contents (300-3770 ppm) and Th/U ratios (0.01-2.12) (Table S2). With the exception of one analysis, Th/ $\mathrm{U}$ ratios are over 0.1 . All apparent ${ }^{206} \mathrm{~Pb} /{ }^{238} \mathrm{U}$ ages of the analyses belong to the Late Triassic. The ages from 90 zircon grains fall in a near concordant cluster (Figure 10c), thus yielding a weighted mean age of 221.4 \pm 0.2 Ma with acceptable analytical uncertainty (MSWD $=0.85)$. The age signifies the timing of syn-sedimentary volcanism.

\subsection{Mylonitized Porphyritic Granite (SY004)}

Zircons from samples SY004 are fine to large (30-240 $\mu \mathrm{m}$ in diameter) and occur as stubby to prismatic (aspect ratios of 1.0-3.7), subhedral to euhedral, and grains with rare rounded terminations. Most zircon grains show oscillatory or sector zoning indicative of igneous origin (Figure 9c). Some zircon grains show inherited anhedral to subhedral zoned cores and weakly zoned overgrowths characterized by dark CL images (Figure 9c). In sample SY004, the isotopic data from 34 zircons reveal a wide range of $U$ contents $(72-3342 \mathrm{ppm})$ and $\mathrm{Th} / \mathrm{U}$ ratios $(0.02-1.86)$ (Table $\mathrm{S} 2)$. With the exception of 
one analysis, $\mathrm{Th} / \mathrm{U}$ ratios are over 0.1 . All apparent ${ }^{206} \mathrm{~Pb} /{ }^{238} \mathrm{U}$ ages of the analyses correspond to the Late Triassic; the ages of 28 zircon grains fall in a near concordant cluster (Figure 10d), thus yielding a weighted mean age of $218.8 \pm 0.43 \mathrm{Ma}$ with acceptable analytical uncertainty $(\mathrm{MSWD}=1.17)$. The age likely indicates the timing of the original crystallization of the mylonitic granite.

\section{Discussion and Conclusions}

Orogenic belts commonly experience late-orogenic or post-orogenic crustal stretching and thinning, accompanied by mantle-derived magmatism, regional thermal metamorphism, and surficial denudation and sedimentation ([59-61]; and more references). The western Gyeonggi Massif has been found to preserve post-orogenic thermal, mechanical, and physiochemical processes following the Early Mesozoic collisional orogeny related to the closure of the Paleo-Tethys Ocean. Late Triassic magmatism [36,37,62], related metamorphism and anatexis [38], and Late Triassic to Early Jurassic non-marine sedimentation [29,32] have been considered as evidence of post-collisional processes in the western Gyeonggi Massif, leading to various conceptual models regarding collision zone architecture. We provide our model below (Figure 11).

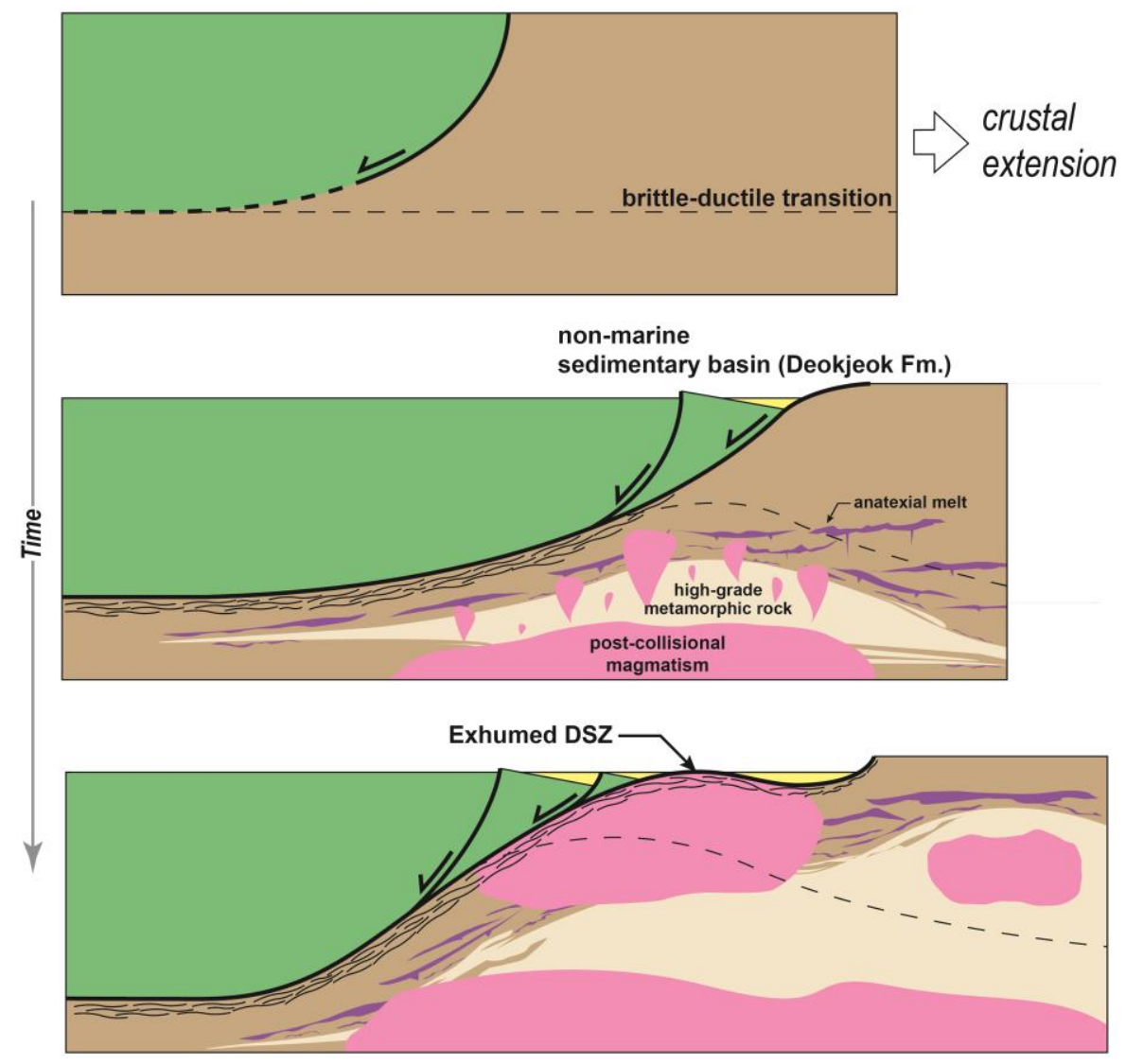

Figure 11. Schematic diagrams showing the formation and evolution of the Deokjeok Shear Zone in relation to the orogenic collapse started from the Late Triassic in the western Gyeonggi Massif.

An important question arises about what style of crustal deformation processes occurred in the western Gyeonggi Massif during the Late Triassic post-collisional stage. Our new microstructural and zircon $\mathrm{U}-\mathrm{Pb}$ isotopic data help clarify the post-collisional crustal deformation history in the study area (Figure 11). Late Triassic post-collisional granite bodies in the Deokjeok and Soya islands were emplaced at ca. 223-218 Ma ([47]; this study: Figures 2 and 10), and were ductilely deformed at mid-crustal levels as estimated from deformation temperature of $\sim 300-400{ }^{\circ} \mathrm{C}$ in the DSZ and SSZ. In the Deokjeok Formation, the ca. $221 \mathrm{Ma}$ and ca. $217 \mathrm{Ma}$ zircon U-Pb ages from the volcanic layers (Figure 10) indicate that the surficial volcano-sedimentary process was nearly simultaneous 
with the deep emplacement of the post-collisional granite. Note that the extensional DSZ with a top-down-to-the-northeast sense of shear now marks the contact between the volcano-sedimentary sequence in the hanging wall and the post-collisional granites in the footwall (Figure 3). Furthermore, the volcano-sedimentary sequence shows a foliated cataclasite along the fault contact with the DSZ (Figure 5), suggesting exhumation of the DSZ to the upper crustal level during progressive extensional shearing. This means that the extensional DSZ had likely evolved in connection with the Late Triassic upper crustal extension and the sedimentation of the Deokjeok Formation. Given these structural features, we suggest that the DSZ with a minimum width of $1 \mathrm{~km}$ played a role as an extensional detachment during the Late Triassic orogenic collapse in the western Gyeonggi Massif (Figure 11). Generally, in collapsing orogens, extensional detachments are known to sole into the middle crust [63]; moreover, they are ubiquitous structures in collapsed orogens, thereby exposing metamorphic core complexes, as can be seen in the Cordillera [64,65], the Caledonides [66], and the Cyclades [67]. The ubiquitous occurrence of extensional detachments in exhumed orogens indicates that the gravitational potential energy, driving vertical thinning and horizontal extension, is a common mode in thickened orogenic crusts $[4,8]$. Our detachment model for DSZ offers a partial explanation for why migmatitic Neoarchean crystalline rock $[68,69]$ is locally exposed in the footwall side of the DSZ (Daeijak Island: Figure 1). Strong Late Triassic zircon overgrowths in the migmatitic Neoarchean rock [70] might indicate decompression-driven partial melting [9,71] during the exhumation, along with extensional shearing along the DSZ. Detailed petrographic and geochronological studies to clarify the characteristics of the P-T-t path of the migmatitic Neoarchean crystalline rock are required to test our detachment model for the DSZ.

The microstructural evidence of structural inversion in the SSZ (Figure 8b) indicates the imprint of a new orogenic cycle following the Late Triassic orogenic collapse in the western Gyeonggi Massif. Extensional shear zones formed during the orogenic collapse might provide an easy target for reactivation as an inherited structure during successive orogenic events [72]. The SSZ was likely formed during the reactivation of an extensional shear zone, which formerly experienced top-down-to-the-northeast movements, in response to regional contraction, and had carried mid-crustal materials southwestward upon the volcano-sedimentary sequence of the Deokjeok Formation (Figure 3). The SSZ was possibly widened with time toward the massive hanging wall (NE block), considering that evidence of reactivation is limited to the lower (southwestern) portion of the SSZ. The progressive contractional shearing along the SSZ at the mid- to upper-crustal levels has been well documented as the crystal plastic deformation overprinted by cataclasis along the southwestern boundary of the SSZ (Figure 8f). In the study area, the NW-SE trending basement-involved thrusts (Buk-ri Thrust: Figure 2) is interpreted to be genetically linked to the SSZ, considering their geometric and kinematic consistency. An important question then arises about when the contractional deformation and the structural inversion occurred. Park et al. [29,30] argued that the structural inversion of post-collisional extensional basins in the western Gyeonggi Massif occurred during the Late Jurassic to Early Cretaceous (ca. 158-110 Ma), as indicated by illite and altered K-feldspar K-Ar geochronology, coupled with detailed structural mapping. They reported that the Late Jurassic to Early Cretaceous structural inversion was contemporaneous with magmatic quiescence across the Korean Peninsula, possibly because of flat/low-angle subduction of the Paleo-Pacific Plate; they further suggested the Laramide-style 'non-magmatic phase' of the Daebo Orogeny. Although further detailed geochronological studies are required, we suggest that the Late Jurassic to Early Cretaceous subduction tectonics were attributed to the ductile contractional shearing and basement-involved thrusting following the Late Triassic orogenic collapse in the study area.

Our study provides insight into the complex crustal structures formed during cyclic orogenic evolution in the western Gyeonggi Massif. As part of the diachronous interplay between tectonic plates and related thermo-mechanical processes in the East Asia continent, the results reflect a Mesozoic tectonic transition from the collision-related Songrim Orogeny to the subduction-related Daebo Orogeny in the Korean Peninsula. 
Supplementary Materials: The following are available online at http://www.mdpi.com/2075-163X/10/4/362/s1, Table S1: SHRIMP U-Pb isotopic data of zircons from a deformed felsic tuff in the Deokjeok Formation. Table S2: LA-MC-ICP-MS U-Pb isotopic data of zircons from a mylonitized porphyritic granite in the Soya Shear Zone and a deformed quartz porphyry in the Deokjeok Formation.

Author Contributions: Conceptualization, S.-I.P.; methodology, J.-Y.P., S.-I.P. and T.C.; investigation, J.-Y.P.; visualization, J.-Y.P. and S.-I.P.; writing—original draft preparation, J.-Y.P.; writing—review and editing, S.-I.P. and T.C.; This work represents part of J.-Y.P.'s Masters Research performed at the Kyungpook National University. All authors have read and agreed to the published version of the manuscript.

Funding: This work was supported by the National Research Foundation of Korea grant which was funded by the Ministry of Science and ICT, Korea to S.-I. Park (Grant no. 2018R1C1B6003851). The research was also partly supported by the Korea Basic Science Institute under the R\&D program (Project No. C030440) supervised by the Ministry of Science and ICT, Korea.

Acknowledgments: We thank Deung-Lyong Cho and Seung-Bae Lee for their guidance to the geology of the Deokjeok and Soya islands in the early stages of this study. We acknowledge Youn-Joong Jeong and Keewook Yi for their professional comments on LA-MC-ICP-MS and SHRIMP zircon dating.

Conflicts of Interest: The authors declare no conflict of interest. The funders had no role in the design of this study; in the collection, analyses, or interpretation of data; in the writing of the manuscript; or in the decision to publish the results.

\section{References}

1. Dewey, J.F.; Bird, J.M. Mountain belts and the new global tectonics. J. Geophys. Res. 1970, 75, $2625-2647$. [CrossRef]

2. Jamieson, R.A.; Beaumont, C. On the origin of orogens. Geol. Soc. Am. Bull. 2013, 125, 1671-1702. [CrossRef]

3. Wilson, J.T. Did the Atlantic close and then re-open? Nature 1966, 211, 676-681. [CrossRef]

4. Jones, C.H.; Unruh, J.R.; Sonder, L.J. The role of gravitational potential energy in active deformation in the southwestern United States. Nature 1996, 381, 37-41. [CrossRef]

5. Schmalholz, S.M.; Medvedev, S.; Lechmann, S.M.; Podladchikov, Y. Relationship between tectonic overpressure, deviatoric stress, driving force, isostasy and gravitational potential energy. Geophys. J. Int. 2014, 17, 680-696. [CrossRef]

6. Jiménez-Munt, I.; Garcia-Castellanos, D.; Negredo, A.M.; Platt, J.P. Gravitational and tectonic forces controlling postcollisional deformation and the present-day stress field of the Alps: Constraints from numerical modeling. Tectonics 2005, 24, TC5009. [CrossRef]

7. Dewey, J.F. Extensional collapse of orogens. Tectonics 1988, 7, 1123-1139. [CrossRef]

8. Rey, P.; Vanderhaeghe, O.; Teyssier, C. Gravitational collapse of the continental crust: Definition, regimes and modes. Tectonophysics 2001, 342, 435-449. [CrossRef]

9. Teyssier, C.; Whitney, D.L. Gneiss domes and orogeny. Geology 2002, 30, 1139-1142. [CrossRef]

10. Bonev, N.; Beccaletto, L. From syn-to post-orogenic Tertiary extension in the north Aegean region: Constraints on the kinematics in the eastern Rhodope-Thrace, Bulgaria-Greece and the Biga Peninsula, NW Turkey. In The Geodynamics of the Aegean and Anatolia; Taymaz, T., Y1lmaz, Y., Dilek, Y., Eds.; Geological Society of London Special Publication: London, UK, 2007; Volume 291, pp. 113-142.

11. Hartz, E. Early syndepositional tectonics of East Greenland's Old Red Sandstone basin. In New Perspectives on the Old Red Sandstone; Friend, P.F., Williams, B.P.J., Eds.; Geological Society of London Special Publication: London, UK, 2000; Volume 180, pp. 537-555.

12. Oh, C.W.; Kim, S.W.; Choi, S.G.; Zhai, M.; Guo, J.; Krishnan, S. First finding of eclogite facies metamorphic event in South Korea and its correlation with the Dabie-Sulu Collision Belt in China. J. Geol. 2005, 113, 226-232. [CrossRef]

13. Kim, S.W.; Kee, W.-S.; Lee, S.R.; Santosh, M.; Kwon, S. Neoproterozoic plutonic rocks from the western Gyeonggi massif, South Korea: Implications for the amalgamation and break-up of the Rodinia supercontinent. Precambrian Res. 2013, 227, 349-367. [CrossRef]

14. Kim, S.W.; Cho, D.-L.; Lee, S.-B.; Kwon, S.; Park, S.-I.; Santosh, M.; Kee, W.-S. Mesoproterozoic magmatic suites from the central-western Korean Peninsula: Imprints of Columbia disruption in East Asia. Precambrian Res. 2018, 306, 155-173. [CrossRef] 
15. Park, S.-I.; Kim, S.W.; Kwon, S.; Santosh, M.; Ko, K.; Kee, W.-S. Nature of Late Mesoproterozoic to Early Neoproterozoic magmatism in the western Gyeonggi massif, Korean Peninsula and its tectonic significance. Gondwana Res. 2017, 47, 291-307. [CrossRef]

16. Kwon, S.; Sajeev, K.; Mitra, G.; Park, Y.; Kim, S.W.; Ryu, I.-C. Evidence for Permo-Triassic collision in Far East Asia: The Korean collisional orogen. Earth Planet. Sci. Lett. 2009, 279, 340-349. [CrossRef]

17. Cho, M.; Lee, Y.; Kim, T.; Cheong, W.; Kim, Y.; Lee, S.R. Tectonic evolution of Precambrian basement massifs and an adjoining fold-and-thrust belt (Gyeonggi Marginal Belt), Korea: An overview. Geosci. J. 2017, 21, 845-865. [CrossRef]

18. Oh, C.W.; Kusky, T. The Late Permian to Triassic Hongseong-Odesan Collision Belt in South Korea, and its tectonic correlation with China and Japan. Int. Geol. Rev. 2007, 49, 636-657. [CrossRef]

19. Zhai, M.; Guo, J.; Li, Z.; Chen, D.; Peng, P.; Li, T.; Hou, Q.; Fan, Q. Linking the Sulu UHP belt to the Korean Peninsula: Evidence from eclogite, Precambrian basement, and Paleozoic sedimentary basins. Gondwana Res. 2007, 12, 388-403. [CrossRef]

20. Lee, D.S. Geology of Korea; Geological Society of Korea: Seoul, Korea, 1987; p. 514.

21. Lee, S.R.; Cho, M. Tectonometamorphic evolution of the Chuncheon amphibolite, central Gyeonggi massif, South Korea. J. Metamorph. Geol. 1995, 13, 315-328. [CrossRef]

22. Lee, S.R.; Cho, M. Metamorphic and tectonic evolution of the Hwacheon Granultie Complex, central Korea: Composite P-T path resulting from two distinct crustal-thickening events. J. Petrol. 2003, 44, 197-225. [CrossRef]

23. Lee, B.C.; Oh, C.W.; Yengkhom, K.S.; Yi, K. Paleoproterozoic magmatic and metamorphic events in the Hongcheon area, southern margin of the Northern Gyeonggi Massif in the Korean Peninsula, and their links to the Paleoproterozoic orogeny in the North China Craton. Precambrian Res. 2014, 248, 17-38. [CrossRef]

24. Oh, C.-W.; Imayama, T.; Yi, S.-B.; Kim, T.; Ryu, I.-C.; Jeon, J.; Yi, K. Middle Paleozoic metamorphism in the Hongseong area, South Korea, and tectonic significance for Paleozoic orogeny in northeast Asia. J. Asian Earth Sci. 2014, 95, 203-216. [CrossRef]

25. Kim, S.W.; Oh, C.W.; Williams, I.S.; Rubatto, D.; Ryu, I.-C.; Rajesh, V.J.; Kim, C.-B.; Guo, J.; Zhai, M. Phanerozoic high-pressure eclogite and intermediate-pressure granulite facies metamorphism in the Gyeonggi Massif, South Korea: Implications for the eastward extension of the Dabie-Sulu continental collision zone. Lithos 2006, 92, 357-377. [CrossRef]

26. Kim, S.W.; Williams, I.S.; Kwon, S.; Oh, C.W. SHRIMP zircon geochronology, and geochemical characteristics of metaplutonic rocks from the south-western Gyeonggi Block, Korea: Implications for Paleoproterozoic to Mesozoic tectonic links between the Korean Peninsula and eastern China. Precambrian Res. 2008, 162, 475-497. [CrossRef]

27. Park, S.-I.; Kim, S.W.; Kwon, S.; Thanh, N.X.; Yi, K.; Santosh, M. Paleozoic tectonics of the southwestern Gyeonggi massif, South Korea: Insights from geochemistry, chromian-spinel chemistry and SHRIMP U-Pb geochronology. Gondwana Res. 2014, 26, 684-698. [CrossRef]

28. Park, S.-I.; Kwon, S.; Kim, S.W.; Yi, K.; Santosh, M. Continental origin of the Bibong eclogite, southwestern Gyeonggi massif, South Korea. J. Asian Earth Sci. 2014, 95, 192-202. [CrossRef]

29. Park, S.-I.; Kwon, S.; Kim, S.W.; Hong, P.S.; Santosh, M. A Mesozoic orogenic cycle from post-collision to subduction in the southwestern Korean Peninsula: New structural, geochemical, and chronological evidence. J. Asian Earth Sci. 2018, 157, 166-186. [CrossRef]

30. Park, S.-I.; Noh, J.; Cheong, H.J.; Kwon, S.; Song, Y.; Kim, S.W.; Santosh, M. Inversion of two-phase extensional basin systems during subduction of the Paleo-Pacific Plate in the SW Korean Peninsula: Implication for the Mesozoic “Laramide-style" orogeny along East Asian continental margin. Geosci. Front. 2019, 10, 909-925. [CrossRef]

31. Lee, B.C.; Oh, C.W.; Kim, T.S.; Yi, K. The metamorphic evolution from ultrahigh-temperature to amphibolite facies metamorphism in the Odaesan area after the collision between the North and South China Cratons in the Korean Peninsula. Lithos 2016, 256-257, 109-131. [CrossRef]

32. Lee, H.; Park, S.-I.; Choi, T.; Sim, M.S. Post-collisional denudation of an orogenic belt traced from geochronological and bulk-rock geochemical records of the western Korean Peninsula. Int. Geol. Rev. 2019, 1-22. [CrossRef]

33. Cluzel, D. Late Palaeozoic to early Mesozoic geodynamic evolution of the Circum-Pacific orogenic belt in South Korea and Southwest Japan. Earth Planet. Sci. Lett. 1991, 108, 298-305. [CrossRef] 
34. Chough, S.K.; Kown, S.-T.; Ree, J.-H.; Choi, D.K. Tectonic and sedimentary evolution of the Korean peninsula: A review and new view. Earth Sci. Rev. 2000, 52, 175-235. [CrossRef]

35. Kim, H.S.; Ree, J.-H.; Kim, J. Tectonometamorphic evolution of the Permo-Triassic Songrim (Indosinian) orogeny: Evidence from the late Paleozoic Pyeongan Supergroup in the northeastern Taebaeksan Basin, South Korea. Int. J. Earth Sci. 2012, 101, 483-498. [CrossRef]

36. Williams, I.S.; Cho, D.-L.; Kim, S.W. Geochronolgy, and geochemical and Nd-Sr isotopic characteristics, of Triassic plutonic rocks in the Gyeonggi Massif, South Korea: Constraints on Triassic post-collisional magmatism. Lithos 2009, 107, 239-256. [CrossRef]

37. Kim, S.W.; Kwon, S.; Koh, H.J.; Yi, K.; Jeong, Y.-J.; Santosh, M. Geotectonic framework of Permo-Triassic magmatism within the Korean Peninsula. Gondwana Res. 2011, 20, 865-889. [CrossRef]

38. De Jong, K.; Han, S.; Ruffet, G. Fast cooling following a Late Triassic metamorphic and magmatic pulse: Implications for the tectonic evolution of the Korean collision belt. Tectonophysics 2015, 662, 271-290. [CrossRef]

39. Park, Y.S.; Kim, S.W.; Kee, W.-S.; Jeong, Y.-J.; Yi, K.; Kim, J. Middle Jurassic tectono-magmatic evolution in the southwestern margin of the Gyeonggi Massif, South Korea. Geosci. J. 2009, 13, 217-231. [CrossRef]

40. Kee, W.-S.; Kim, S.W.; Jeong, Y.-J.; Kwon, S. Characteristics of Jurassic continental arc magmatism in South Korea: Tectonic implications. J. Geol. 2010, 118, 305-323. [CrossRef]

41. Kim, S.W.; Kwon, S.; Ko, K.; Yi, K.; Cho, D.-L.; Kee, W.-S.; Kim, B.C. Geochronological and geochemical implications of Early to Middle Jurassic continental adakitic arc magmatism in the Korean Peninsula. Lithos 2015, 227, 225-240. [CrossRef]

42. Lim, C.; Cho, M. Two-phase contractional deformation of the Jurassic Daebo Orogeny, Chungnam Basin, Korea, and its correlation with the early Yanshanian movement of China. Tectonics 2012, 31, TC1004. [CrossRef]

43. Kim, Y.; Aum, H.W.; Choeng, W.; Kim, T.; Yi, K. An occurrence of the post-orogenic Triassic strata on Deokjeok Island, western Gyeonggi massif, Korea. Geosci. J. 2014, 18, 137-147. [CrossRef]

44. Cho, D.-L.; Lee, S.-b. Geological Report of the Gureopdo-Deokjeokdo-Baegado-Seongapdo Sheets (1:50,000); Korea Institute of Geoscience and Mineral Resources: Daejeon, Korea, 2016. (In Korean with English abstract).

45. Cluzel, D. Formation and tectonic evolution of early Mesozoic intramontane basins in the Ogcheon belt (South Korea): A reappraisal of the Jurassic “Daebo orogeny". J. Southeast Asian Earth Sci. 1992, 7, 223-235. [CrossRef]

46. Zheng, Y.-F.; Xiao, W.-J.; Zhao, G. Introduction to tectonics of China. Gondwana Res. 2013, 23, 1189-1206. [CrossRef]

47. Kim, S.W.; Kwon, S.; Santosh, M.; Cho, D.-L.; Kee, W.-S.; Lee, S.-B.; Jeong, Y.-J. Detrital zircon U-Pb and Hf isotope characteristics of the Early Neoproterozoic successions in the central-western Korean Peninsula: Implication for the Precambrian tectonic history of East Asia. Precambrian Res. 2019, 322, 24-41. [CrossRef]

48. Hirth, G.; Tullis, J. Dislocation creep regimes in quartz aggregates. J. Struct. Geol. 1992, 14, 145-159. [CrossRef]

49. Stipp, M.; Stünitz, H.; Heilbronner, R.; Schmid, S.M. The eastern Tonale fault zone: A 'natural laboratory' for crystal plastic deformation of quartz over a temperature range from 250 to $700{ }^{\circ}$ C. J. Struct. Geol. 2002, 24, 1861-1884. [CrossRef]

50. Stipp, M.; Stünitz, H.; Heilbronner, R.; Schmid, S.M. Dynamic recrystallization of quartz: Correlation between natural and experimental conditions. In Deformation Mechanism, Rheology and Tectonics: Current Status and Future Perspectives; De Meer, S., Drury, M.R., De Bresser, J.H.P., Pennock, G.M., Eds.; Special Publications of the Geological Society of London: London, UK, 2002; Volume 200, pp. 171-190.

51. Pryer, L.L. Microstructures in feldspars from a major crustal thrust zone: The Grenville Front, Ontario, Canada. J. Struct. Geol. 1993, 15, 21-36. [CrossRef]

52. Paces, J.B.; Miller, J.D. Precise U-Pb ages of Duluth Complex and related mafic intrusions, Northeastern Minnesota: Geochronological insights to physical, petrogenetic, paleomagnetic, and tectonomagmatic processes associated with the 1.1 Ga midcontinent rift system. J. Geophys. Res. 1993, 98, 13997-14013. [CrossRef]

53. Sláma, J.; Košler, J.; Condon, D.J.; Crowley, J.L.; Gerdes, A.; Hanchar, J.M.; Horstwood, M.S.A.; Morris, G.A.; Nasdala, L.; Norberg, N.; et al. Plešovice zircon-A new natural reference material for U-Pb and Hf isotopic microanalysis. Chem. Geol. 2008, 249, 1-35. [CrossRef] 
54. Steiger, R.H.; Jäger, E. Subcommision on geochronology: Convention on the use of decay constants in geo-and cosmochronology. Earth Planet. Sci. Lett. 1977, 36, 359-362. [CrossRef]

55. Ludwig, K.R. User's Manual for Isoplot 3.6: A Geochronological Toolkit for Microsoft Excel; Berkeley Geochronology Center Special Publication: Berkeley, CA, USA, 2008.

56. Ludwig, K.R. User's Manual for SQUID 2; Berkeley Geochronology Center Special Publication: Berkeley, CA, USA, 2009.

57. Paton, C.; Woodhead, J.D.; Hellstrom, J.C.; Hergt, J.M.; Greig, A.; Maas, R. Improved laser ablation U-Pb zircon geochronology through robust downhole fractionation correction. Geochem. Geophys. Geosyst. 2010, 11, Q0AA06. [CrossRef]

58. Paton, C.; Hellstrom, J.; Paul, B.; Woodhead, J.; Hergt, J. Iolite: Freeware for the visualization and processing of mass spectrometric data. J. Anal. Atom. Spectrom. 2011, 26, 2508-2518. [CrossRef]

59. England, P.; Houseman, G. Extension during continental convergence, with application to the Tibetan Plateau. J. Geophys. Res. 1989, 94, 17561-17579. [CrossRef]

60. Platt, J.P.; England, P.C. Convective removal of lithosphere beneath mountain belts: Thermal and mechanical consequences. Am. J. Sci. 1993, 293, 307-336. [CrossRef]

61. Turner, S.; Arnaud, N.; Lui, J.; Roger, N.; Hawkesworth, C.; Harris, N.; Kelley, S.; van Calsteren, P.; Deng, W. Post-collision, shoshonitic volcanism on the Tibetan Plateau: Implications for convective thinning of the lithosphere and the source of ocean island basalts. J. Petrol. 1996, 37, 45-71. [CrossRef]

62. Choi, S.-G.; Rajesh, V.J.; Seo, J.; Park, J.-W.; Oh, C.-W.; Pak, S.-J.; Kim, S.-W. Petrology, geochronology and tectonic implications of Mesozoic high Ba-Sr granites in the Haemi area, Hongseong Belt, South Korea. Isl. Arc 2009, 18, 266-281. [CrossRef]

63. Platt, J.P.; Behr, W.M.; Cooper, F.J. Metamorphic core complexes: Windows into the mechanics and rheology of the crust. J. Geol. Soc. 2015, 172, 9-27. [CrossRef]

64. Armstrong, R.L. Cordilleran metamorphic core complexes-From Arizona to southern California. Ann. Rev. Earth Planet. Sci. 1982, 10, 129-154. [CrossRef]

65. Lister, G.S.; Davis, G.A. The origin of metamorphic core complexes and detachment faults formed during Tertiary continental extension in the northern Colorado River region, USA. J. Struct. Geol. 1989, 11, 65-94. [CrossRef]

66. Anderson, T.B. Extensional tectonics in the Caledonides of southern Norway, an overview. Tectonophysics 1998, 285, 333-351. [CrossRef]

67. Forster, M.A.; Lister, G.S. Detachment faults in the Aegean core complex of Ios, Cyclades, Greece. In Exhumation Processes: Normal Faulting, Ductile Flow and Erosion; Ring, U., Brandon, M.T., Lister, G.S., Willett, S.D., Eds.; Geological Society of London Special Publication: London, UK, 1999; Volume 154, pp. 305-323.

68. Cho, M.; Kim, H.; Lee, Y.; Horie, J.; Hidaka, H. The oldest (ca. $2.51 \mathrm{Ga}$ ) rock in South Korea: U-Pb zircon age of a tonalitic migmatite, Daeijak Island, western Gyeonggi massif. Geosci. J. 2008, 12, 1-6. [CrossRef]

69. Lee, Y.; Cho, M. Fluid-present disequilibrium melting in Neoarchean arc-related migmatites of Daeijak Island, western Gyeonggi Massif, Korea. Lithos 2013, 179, 249-262. [CrossRef]

70. Kim, Y.; Cheong, C.-S.; Lee, Y.; Williams, I.S. SHRIMP allanite U-Th-Pb dating of bimodal Triassic metamorphism of Neoarchean tonalitic gneisses, Daeijak Island, central Korea. Geosci. J. 2009, 13, 305-315. [CrossRef]

71. Whitney, D.L.; Teyssier, C.; Vanderhaeghe, O. Gneiss domes and crustal flow. In Gneiss Domes in Orogeny; Whitney, D.L., Teyssier, C., Siddoway, C.S., Eds.; Geological Society of America Special Paper: Boulder, CO, USA, 2004; Volume 380, pp. 15-33.

72. Fossen, H.; Cavalcante, G.C.G. Shear zones-A review. Earth-Sci. Rev. 2017, 171, 434-455. [CrossRef]

(C) 2020 by the authors. Licensee MDPI, Basel, Switzerland. This article is an open access article distributed under the terms and conditions of the Creative Commons Attribution (CC BY) license (http://creativecommons.org/licenses/by/4.0/). 